\title{
Коагулопатія як фактор ризику венозних тромбозів та емболій у хворих із гострими неварикозними гастродуодена.љыими кровотечами
}

\begin{abstract}
Мета роботи: дослідити ризик ВТЕ у хворих із гострими шлунково-кишковими кровотечами неварикозного генезу. Матеріали і методи. Проведено аналіз результатів лікування 246 хворих із гострими шлунково-кишковими кровотечами неварикозного генезу. Усім хворим з метою діагностики джерела кровотечі виконували фіброгастродуоденоскопію (ФГДС) для пошуку джерела геморагії та оцінки ризику її рецидиву за класифікацією J. Forrest. Встановлено, що у 83,7 \% хворих джерелом геморагії була пептична виразка дванадцятипалої кишки. Комбінований ін'єкційно-коагуляційний гемостаз застосовували у випадках триваючої геморагії та стигматах нестабільного гемостазу - Forrest 1A (2,5 \%), Forrest 1B (12,8 \%) та Forrest 2A (10,3 \%), Forrest 2B (19,4 \%), відповідно. Померли 10 хворих із ГШКК (загальна летальність - 4,1 \%), жоден - від триваючої кровотечі. Причиною летального результату в усіх випадках визнано серцево-легеневу недостатність. У 2 померлих під час автопсії виявлено проксимальний флеботромбоз, у 4 - тромбоз та емболію сегментарних гілок легеневої артерії. Стан системи гемостазу оцінювали за показниками стандартної коагулограми.

Результати досліджень та їх обговорення. Проведене дослідження не виявило патологічних відхилень у коагуляційних тестах у 70,3 \% хворих з ГШКК, гіперкоагуляцію - у 25,3 \%, гіпокоагуляцію - у 4,4 \% пацієнтів. Про підвищений потенціал крові до зсідання свідчили вкорочення часу зсідання крові, протромбінового часу, підвищений рівень розчинних комплексів фібрину мономерів (РКМФ). Усі хворі на ГШКК, в яких констатовано лабораторні ознаки гіперкоагуляції, мали високий ризик ВТЕ за загальновизнаною шкалою J. Сарrini. Факторами, що зумовили максимальний ризик ВТЕ, були: ліжковий режим більше 72 год, вік 61-74 роки, венозні тромбози в анамнезі, катетеризація центральних вен.

Таким чином, гіперкоагуляція у хворих з гострими неварикозними гастродуоденальними кровотечами при поєднанні з іншими факторами становить високий ризик виникнення венозних тромбозів та емболій.
\end{abstract}

Ключові слова: гострі шлунково-кишкові кровотечі неварикозного генезу; система гемостазу; венозні тромбози і емболії.

Постановка проблеми і аналіз останніх досліджень та публікацій. Венозні тромбози та емболії (ВТЕ) - одне $з$ найтяжчих ускладнень з характерною гостротою та драматичністю перебігу, складністю діагностики, лікування та профілактики і високою летальністю [9]. Утворення тромбу відбувається при появі тріади Вірхова: гіперкоагуляції, сповільнення венозного кровотоку та ушкодження ендотелію [9]. Ці зміни можуть виникнути при різних за походженням уроджених та набутих захворюваннях, патологічних станах, у процесі їх лікування, зокрема після хірургічних втручань. Їх ретельне врахування покладено в основу визначення індивідуального ризику ВТЕ, відтак - диференційованої їх профілактики [8]. Підвищення коагуляційного потенціалу крові є фізіологічною реакцією організму на кровотечу. Проте надмірна та пролонгована гіперкоагуляція в умовах інтенсивної гемостатичної та антифібринолітичної терапії (амінокапронова, транексамова кислоти) у хворих з гострими шлунково-кишковими кровотечами (ГШКК) може спричинити утворення тромбу не тільки в арозованій судині як джерелі геморагії, а й у системному кровотоку [6, 12]. Ризик флеботромбозу є особливо високим у пацієнтів, які у зв’язку з виникненням ГШКК вимушено припинили тривалу антикоагулянтну та антиагрегантну терапію, призначену для профілактики ВТЕ, інфаркту міокарда, тромбоішемічного інсульту [13]. Стан системи гемостазу, незважаючи на численні вітчизняні та зарубіжні дослідження, не є достатньо вивченим, свідченням чого зокрема є протиріччя у висновках авторів $[2,4,5]$. У спеціальній літературі ми не знайшли повідомлень про ризик ВТЕ, зумовлений гіперкоагуляцією, у хворих з ГШКК.

Мета роботи: дослідити ризик ВТЕ у хворих із ГШКК неварикозного генезу.

Матеріали і методи. Дослідженням охоплено 246 хворих із ГШКК неварикозного генезу ві-

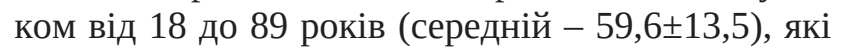
знаходились на лікуванні в центрі ШКК у клініці хірургії та ендоскопії ЛНМУ імені Данила Галицького (клінічна база - 3 хірургічне відділення лікарні швидкої медичної допомоги м. Львова) 3 2012 до 2016 року включно. Переважали чоловіки (67,5 \%). Характерними скаргами хворих були: блювання “кавовою гущею”, незміненою кров’ю та згустками, нудота, дьогтеподібний кал, головокружіння та загальна слабість, втрата свідомості. 
Усім хворим із метою діагностики джерела кровотечі виконували ФГДС, для пошуку джерела геморагії та оцінки ризику її рецидиву за класифікацією J. Forrest. Гострі ерозивно-виразкові ураження як джерела ГШКК виявлено у 40 пацієнтів (16,3 \%): шлунка - 31 (77,5 \%), дванадцятипалої кишки - 2 (5 \%), виразку Делафуа - 7 (17,5 \%). Причиною виникнення ерозій та гострих виразок у всіх випадках було неконтрольоване приймання нестероїдних протизапальних лікарських засобів задля первинної та вторинної профілактики інфаркту міокарда, полегшення болю, спричиненого коксартрозом, спондилітом та ін. Пептичні виразки як джерела ГШКК констатовано у більшості госпіталізованих - 206 (83,7 \%): шлунка 58 (28 \%), дванадцятипалої кишки - 138 (67%), шлунка і дванадцятипалої кишки - 2 (1 \%), гастроентероанастомозу - 8 (4%). Виразковий анамнез тривалістю від 1 до 10 років спостерігали у 70 хворих (34%). Комбінований ін'єкційнокоагуляційний гемостаз застосовували у випадках триваючої геморагії та стигматах нестабільного гемостазу - Forrest 1A (2,5 \%), Forrest 1B (12,8 \%) та Forrest 2A (10,3 \%), Forrest 2B (19,4 \%), відповідно.

У зв’язку з тяжкістю загального стану 75 пацієнтів (30,4 \%) початково були госпіталізовані у відділення анестезіології та інтенсивної терапії. Остання полягала у трансфузії в центральні вени еритроцитарної маси / відмитих еритроцитів (при зменшенні гемоглобіну менше 70 г/л), інфузії кристалоїдних та колоїдних розчинів, застосуванні інгібіторів протонної помпи (омепразол, пантопразол), антацидних засобів (альмагель, фосфалюгель). 3 гемостатичною метою застосовували інфузію свіжозамороженої плазми, розчини амінокапронової, транексамової кислот, вітамін К, препарати кальцію, дицинон. Хворі аж до ФГДСконстатації стабільного гемостазу були на суворому ліжковому режимі. Рецидиви ГШКК у 39 пацієнтів (15,8 \%) виникли протягом перших трьох днів перебування в клініці. У зв’язку з неефективністю ендоскопічної зупинки рецидивної кровотечі у невідкладному порядку оперовано 5 хворих (хірургічна активність - 2 \%), які видужали (післяопераційна летальність - 0 \%). Середній ліжкодень становив $13 \pm 4,3$.

Померли 10 хворих з ГШКК (загальна летальність - 4,1 \%), жоден - від триваючої кровотечі. Причиною летального результату в усіх випадках визнано серцево-легеневу недостатність. У 2 померлих під час автопсії виявлено проксимальний флеботромбоз, у 4 - тромбоз та емболію сегментарних гілок легеневої артерії.
Як і більшість авторів, забір крові для визначення показників зсідальної системи виконували при госпіталізації пацієнта в клініку [6].

Результати досліджень та їх обговорення. Частота гострих кровотеч з верхніх відділів травного тракту неварикозного генезу, за повідомленнями авторів, становить 37-172 на 100 тис. населення і не має тенденції до зниження $[4,10]$. За даними проведеного дослідження, хронічні пептичні виразки шлунка і дванадцятипалої кишки є основними джерелами ГШКК, що істотно перевищує наявні в літературі статистичні дані - 50 [10]. Друге місце за частотою причин ГШКК ерозивно-виразкових уражень, як засвідчили отримані результати, зізвучне з висновками інших клініцистів [10]. Летальність у досліджуваній нами групі хворих виявилась близькою до нижньої межі відповідних літературних даних - 3-25 \% [4, 10]. Примітно, що головною причиною смерті обстежених нами хворих виявилась не, як можна було б припустити, профузна кровотеча і критична за об’ємом крововтрата, а саме серцево-легенева недостатність. До ідентичного висновку прийшли й інші клініцисти [10]. Як відомо, однією з ймовірних причин цього тяжкого ускладнення можуть бути венозні тромбози й емболія легеневої артерії [9]. 3 невідомих причин пацієнтів із тромбоемболічними ускладненнями вилучають 3 досліджень стану системи гемостазу у хворих з ГШКК. 3 іншого боку, клініцисти наголошують на важливій ролі розладів гемостазу не тільки в виникненні ГШКК, а й у тромботичних станів, зокрема дисемінованого внутрішньосудинного зсідання крові - ДВЗ-синдрому [1, 2, 6]. Автори повідомляють про труднощі у досягненні балансу ризику кровотечі і ВТЕ у пацієнтів із ГШКК.

Досліджень системи гемостазу у спеціальній літературі багато, однак висновки клініцистів є різноспрямовані. Отож, більшість повідомлень свідчить про підвищення коагуляційного потенціалу крові при виникненні ГШКК [2, 3, 5]. Значно рідше констатують розвиток гіпокоагуляції як результату втрати плазмово-коагуляційних факторів під час крововтрати [6]. Інші автори вважають, що зміни гемостазу залежать від ступеня крововтрати i мають фазовий характер - гіперкоагуляція змінюється гіпокоагуляцією [4]. Проведене нами дослідження не виявило патологічних відхилень у коагуляційних тестах у 70,3 \% хворих із ГШКК, гіперкоагуляцію - у 25,3 \%, гіпокоагуляцію - у 4,4 \% пацієнтів. Про підвищений потенціал крові до зсідання свідчили вкорочення часу зсідання крові, протромбінового часу, підвищений рівень розчинних комплексів мономерних фібринів (РКМФ). 
Однією 3 ймовірних причин різноспрямованості висновків щодо змін системи гемостазу хворих із ГШКК є значні відмінності у досліджуваних лабораторних тестах зсідальної, протизсідальної та фібринолітичної систем крові. Так, значна кількість авторів застосовує великий перелік тестів, реальний для виконання у наукових, а не загальнолікарняних лабораторій: протромбіновий час з розрахунком Міжнародного нормалізованого відношення (МНВ), активність антитромбіну III, вміст РКМФ, активний частковий тромбопластиновий час (АЧТЧ), фібриноген, кількість тромбоцитів, індукована агрегація тромбоцитів, активований час рекальцифікації, толерантність плазми до гепарину, час зсідання крові, ретракція кров'яного згустка, лізис еуглобулінового згустка, час зсідання за Lee White, паракоагуляційні тести (етанолова, $\beta$-нафтолова проба), каоліновий час зсідання плазми [1-7].

Як відомо, стандартній аналіз показників системи згортання крові (Ф. 237/о, затверджена наказом МО3 України №1 від 04.01.2001 р.) передбачає визначення 14 параметрів, більшість з яких в дійсності не досліджують, як можна припустити, з причини значного недофінансування системи охорони здоров'я. Це створює підгрунтя до необ'єктивної оцінки системи гемостазу госпіталізованих хворих у цілому й з ГШКК зокрема [5]. Автори повідомляють про розбіжності у результатах гемостазіологічних досліджень, зокрема протромбінового часу у різних лабораторіях, зумовлених відмінностями в реактивах і устаткуванні [10]. Оптимізацію дослідження системи гемостазу у хворих на ГШКК клініцисти вбачають у звуженні обсягу показників до АЧТЧ та МНВ [10].

Усі хворі на ГШКК, в яких констатовано лабораторні ознаки гіперкоагуляції, мали високий ризик ВТЕ за загальновизнаною шкалою J. Caprini [8]. Факторами, які зумовили максимальний ризик ВТЕ, були: ліжковий режим більше 72 год, вік 6174 роки, венозні тромбози в анамнезі, катетеризація центральних вен. У померлих хворих, в яких під час автопсії виявлено проксимальний флеботромбоз та емболію сегментарних гілок легеневої артерії, лабораторні показники свідчили про підвищення коагуляційного стану зсідальної системи крові.

Висновки. 1. Основним джерелом гострих неварикозних гастродуоденальних кровотеч $€$ пептична виразка дванадцятипалої кишки.

2. У кожного четвертого хворого з гострими неварикозними гастродуоденальними кровотечами $є$ підвищення коагуляційного стану зсідальної системи крові.

3. Гіперкоагуляція у хворих з гострими неварикозними гастродуоденальними кровотечами при поєднанні з іншими факторами становить високий ризик виникнення венозних тромбозів та емболій.

Перспективи подальших досліджень. Подальші наукові дослідження доцільно зосередити на раціоналізації лабораторної оцінки системи гемостазу, об’єктивізації ризику венозних тромбозів та емболій у хворих з неварикозними гастродуоденальними кровотечами, опрацюванні безпечної профілактики їх виникнення.

\section{СПИСОК ЛІТЕРАТУРИ}

1. Байкова Э. Р. Особенности состояния системы гемостаза у больных язвенной болезнью желудка / Э. Р. Байкова, М. М. Фазлыев, Р. М. Фазлыева // Медицинский вестник Башкортостана. - 2011. - Т. 6, № 6. - С. 25-28.

2. Состояние системы гемостаза у больных с острым язвенным кровотечением / Ю. С. Винник, С. И. Петрушко, Ю. А. Назарьянц [и др.] // Кубанский научный медицинский вестник. - 2013. - № 3(138). - С. 36-39.

3. Язвенная болезнь двенадцатиперстной кишки: состояние системы гемостаза / А. Н. Жданов, Е. Н. Никитин, Н. А. Никитина, А. А. Ворсин // Практическая медицина. - 2011. - № 3 (50). - C. 74.

4. Система гемостаза у пациентов с язвенной болезнью, осложненной кровотечением на фоне артериальной гипертензии / Т. Ю. Кравцова, В. В. Щекотов, В. Н. Репин [и др.] // Пермский медицинский журнал. - 2009. - Т. XXVI, № 2. С. $72-77$.

5. Лавро 3. Я. Гемостазіологічні аспекти виразкової хвороби шлунка і дванадцятипалої кишки, ускладненої шлунково-кишковою кровотечею / З. Я. Лавро, Л. Є. Лаповець, В. М. Акі-

мова // Практична медицина. - 2009. Т. XV, № 1. - С. 82-85. 6. Нарушения в системе гемостаза как фактор риска гастродуоденальных кровотечений / Е. В. Николаев, О. Ю. Боженов, О. А. Костина [и др.] // Дальневосточный медицинский журнал. - 2005. - № 2. - С. 40-43.

7. Изменения в системе гемостаза у больных с острым язвенным гастродуоденальным кровотечением / С. И. Петрушко, Ю. С. Винник, Л. А. Таксанова [и др.] // Сибирское медицинское обозрение. - 2006. - № 3(40). - С. 20-24.

8. Jairath V. Modern-day management of upper gastrointestinal haemorrhage / V. Jairath, M. J. R. Desborough // Transfusion Medicine. - 2015. - Vol. 25. - P. 351-357.

9. Nutbeam T. In adult patients presenting as emergencies with upper gastrointestinal bleeding, does tranexamic acid decrease mortality? / T. Nutbeam // African Journal of Emergency Medicine. - 2015. - № 3. - P. 85-92.

10. Management of anticoagulation in patients with acute gastrointestinal bleeding / F. Radelli, F. Dentali, A. Repici [et al.] // Digestive and Liver Disease. - 2015. - № 8, Vol. 47. P. 621-627. 


\section{REFERENCES}

1. Baykova, Ye.R., Fazlyev, M.M., \& Fazlyeva, R.M. (2011). Osobennosti sostoyaniya sistemy gemostaza u bolnykh yazvennoy boleznyu zheludka [Features of hemostasis sestem in stomach ulcer patients]. Meditsinskiy vestnik Bashkortostana - Medical Journal Bashkorstan, 6 (6), 25-28 [in Russian].

2. Vinnik, Yu.S., Petrushko, S.I., Nazaryants, Yu.A., Kochetova, L.V., Kuznetsov M.N., Vasilenya, E.S., Pakhomova, R.A. et al. (2013). Sostoyanie sistemy gemostaza u bolnykh s ostrym yazvennym krovotecheniem [Condition of system of the hemostasis in patients with acute ulcerative gastroduodenum bleeding]. Kubanskiy nauchnyy meditsinskiy vestnik - Kuban Scientific Medical Journal, 3 (138), 36-39 [in Russian].

3. Zhdanov, A.N., Nikitin, E.N., Nikitina, N.A., \& Vorsin, A.A. (2011). Yazvennaya bolezn dvenadtsatiperstnoy kishki: sostoyanie sistemy gemostaza. [Duodenal ulcer, the condition of hemostatic system]. Prakticheskaya meditsina - Practical Medicine, 3 (50), 74 [in Russian].

4. Kravtsova, T.Yu., Shchekotov, V.V., Repin, V.N., Vachegina, O.M., \& Kostylev, L.M. (2009). Sistema gemostaza u patsientov s yazvennoy boleznyu, oslozhnennoy krovotecheniem na fone arterialnoy gipertenzii [Hemostasis system in patients with stomach ulcer complicated by hemorrhage against a background of arterial hypertension]. Permskiy meditsinskiy zhurnal - Perm Medical Journal, XXVI (2), 72-77 [in Russian].

5. Lavro, Z.Ya., Lapovets, L.Ye., \& Akimova, V.M. (2009). Hemostaziolohichni aspekty vyrazkovoi khvoroby shlunka i dvanadtsiatypali kyshky, uskladneni shlunkovo-kyshkovoiu krovo- techeiu [Gemostatic aspects of ulcerous illness of stomach and duodenum, complicated the gastroenteric bleeding]. Praktychna medytsyna - Practical Medicine, 1 (15), 82-85 [in Ukrainian].

6. Nikolaev, E.V., Bozhenov, O.Yu., Kostina, O.A., Maslakova, N.P., Karagodina, N.A., Kriventsova, N.V., \& Tomsinskaya, M.V. (2005). Narusheniya v sisteme gemostaza kak faktor riska gastroduodenalnykh krovotecheniy [Homeostasis impairments as risk factor of ulcer gastro duodenal bleeding]. Dalnevostochnyy meditsinskiy zhurnal - Far Eastern Medical Journal, 2, 40-43 [in Russian].

7. Petrushko, S.I., Vinnik, Yu.S., Taksanova, L.A., Balahonov, V.V., \& Popov, D.V. (2006). Izmeneniya v sisteme gemostaza u bolnykh s ostrym yazvennym gastroduodenalnym krovotecheniem [The condition of haemostatic system of the patients with an acute ulcer gastroduodenal bleeding]. Sibirskoe meditsinskoe obozrenie Siberian Medical Review, 3 (40), 20-24 [in Russian].

8. Jairath, V. \& Desborough, M. (2015). Modern-day management of upper gastrointestinal haemorrhage. Transfusion Medicine, 25 (6), 351-357.

9. Nutbeam, T. (2015). In adult patients presenting as emergencies with upper gastrointestinal bleeding, does tranexamic acid decrease mortality? African Journal of Emergency Medicine, 5 (2), 85-92.

10. Radaelli, F., Dentali, F., Repici, A., Amato, A., Paggi, S., Rondonotti, E. \& Dumonceau, J. (2015). Management of anticoagulationin patients with acute gastrointestinal bleedig. Digestive and Liver Disease, 47 (8), 621-627.

Отримано 21.06.2017

\section{B. O. MATVIYCHUK ${ }^{1}$, T. I. BETS ${ }^{1}$, V. Z. MAKARA ${ }^{2}$}

Danylo Halytskyi Lviv National Medical University ${ }^{1}$

Lviv Municipal City Emergency Care Clinical Hospital²

\section{COAGULOPATHY AS A RISK FACTOR OF VENOUS THROMBOEMBOLISM IN PATIENTS WITH ACUTE NONVARICEAL GASTROINTESTINAL BLEEDING}

The aim of the works: risk evaluation of venous thromboembolism in patients with acute nonvariceal gastrointestinal bleeding. Materials and Methods. Treatment results of 246 with acute nonvariceal gastrointestinal bleeding was carried out. Gastroduodenoscopy had been performed aiming to recognize source of bleeding and risk of rebleeding in accordance with J. Forrest classification as well. Duodenal peptic ulcer disease was recognized as main source of bleeding in $83.7 \%$ of patients. Endoscopic haemostasis had performed in patients with ongoing bleeding and high risk of its recurrence: Forrest $1 \mathrm{~A}(2.5 \%)$, Forrest 1B (12.8 \%) and Forrest 2A (10.3\%), Forrest 2B (19.4\%), respectively. Ten patients died (mortality $-4.1 \%$ ) but no one from ongoing bleeding. Acute cardiopulmonary insufficiency as the main cause of death was recognized. Proximal deep vein thrombosis was revealed in 2 patients and in 4 cases - pulmonary thromboembolism. Coagulation status was evaluated in accordance with local protocol.

Results and Discussion. In $70.3 \%$ of patients coagulation tests were in the normal limits, whereas hypercoagulation and hypocoagulation were recognized in $25.3 \%$ and $4.4 \%$ of cases, respectively. Hypercoagulation was recognized when shortening of clotting time, prothrombin time and elevated concentration of D-dimers were revealed. High risk of VTE according with Caprini score was calculated. Main VTE - risk factors were recognized: prolonged bed rest - more than 72 hours, age 61-74 years, previous VTE, central vein catheterization.

Conclusions. Hypercoagulation in patients with acute nonvariceal gastrointestinal bleeding combined with other factors constitutes high risk of VTE.

Key words: acute nonvariceal gastrointestinal bleeding; coagulopathy; venous thromboembolism. 


\author{
Б. О. МАТВИЙЧУКํำ Т. И. БЕЦ', В. 3. МАКАРА²
}

Львовский национальный медицинский университет имени Данила Галицкого ${ }^{1}$

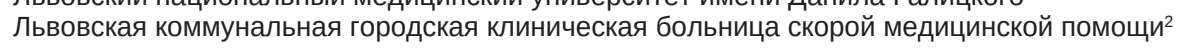

\title{
КОАГУЛОПАТИЯ КАК ФАКТОР РИСКА ВЕНОЗНЫХ ТРОМБОЗОВ И ЭМБОЛИЙ У БОЛЬНЫХ С ОСТРЫМИ НЕВАРИКОЗНЫМИ ГАСТРОДУОДЕНАЛЫНЫМИ КРОВОТЕЧЕНИЯМИ
}

Цель работы: исследовать риск ВТЭ у больных с острыми желудочно-кишечными кровотечениями неварикозного генеза. Материалы и методы. Проведен анализ результатов лечения 246 больных с острыми желудочно-кишечными кровотечениями неварикозного генеза. Всем больным с целью диагностики источника кровотечения выполняли фиброгастродуоденоскопию (ФГДС) для поиска источника геморрагии и оценки риска ее рецидива по классификации J. Forrest. Установлено, что в 83,7 \% больных источником геморрагии была язва двенадцатиперстной кишки. Комбинированный инъекционно-коагуляционный гемостаз применяли в случаях продолжающейся геморрагии и стигматах нестабильного гемостаза - Forrest $1 \mathrm{~A}$ (2,5 \%), Forrest 1B (12,8 \%) и Forrest 2A (10,3 \%), Forrest 2B (19,4\%), в соответствии. Умерли 10 больных с острыми желудочнокишечными кровотечениями (ОЖКК) (общая летальность - 4,1 \%) ни один - от продолжающегося кровотечения. Причиной летального исхода во всех случаях признано сердечно-легочную недостаточность. В 2 умерших во время аутопсии обнаружено проксимальный флеботромбоз, у 4 - тромбоз и эмболию сегментарных ветвей легочной артерии. Состояние системы гемостаза оценивали по показателям стандартной коагулограммы.

Результаты исследований и их обсуждение. Проведенное исследование не обнаружыло патологических отклонений в коагуляционных тестах в 70,3 \% больных с ОЖКК, гиперкоагуляции - в 25,3 \%, гипокоагуляцию - в 4,4 \% пациентов. О повышенном потенциале крови к свертыванию свидетельствовали: уменьшение времени свертывания крови, протромбинового времени, повышенный уровень растворимых комплексов мономерных фибринов (РКМФ). Все больные ОЖКК, в которых констатировано лабораторные признаки гиперкоагуляции, имели высокий риск ВТЭ по общепризнанной шкале Ј. Саргіni. Факторами, которые обусловили максимальный риск ВТЭ, были: постельный режим более 72 ч, возраст 61-74 года, венозные тромбозы в анамнезе, катетеризация центральных вен.

Таким образом, гиперкоагуляция у больных с острыми неварикозными гастродуоденальными кровотечениями при сочетании с другими факторами составляет высокий риск возникновения венозных тромбозов и эмболии.

Ключевые слова: острые желудочно-кишечные кровотечения неварикозного генеза; система гемостаза; венозные тромбозы и эмболии. 